\title{
Current Forum
}

\section{地球圏 一生物圏国際協同研究計画 ——地球変化の研究 (International Geosphere-Bioshere Program — A study of Global Change —, IGBP と略称) の紹介と意見}

\author{
古 坂 澄 石
}

\section{1.はじめに}

地球の環境污染が進み, このまま污染が進行すれば 全人類の存亡にも拘わるとの警告が発せられてから既 に四半世紀が過ぎようとしている。 $\mathrm{CO}_{2}$ や $\mathrm{CH}_{4}$ 等の 増加に伴ら地球の温暖化, フロンガスによるオゾン層 の破壊，ならびに工業拉よび自動車排気ガス等による 酸性雨問題等の諸問題が, 近年再びジャーナリズムを 賑わわすよらになってきた。国際政治の面でもヨー ロッパを中心に対策を探る動きが出て来たことは, 遅 過ぎたきらいはあるものの望ましいことである。この 動きにつられて日本政府も地球変化の実態解明と污染 防止のために多額の資金を據出することになった。そ 乙て通産省, 農水省, 環境庁等の政府機関は競争して 研究態制の再編に動き出している。学術会議も, 国際 測地学 一地球物理学会 (IUGG) の提案による地球圈 一生物圈国際協同研究計画一地球変化の研究-に 参加することに決し, 特別委員会を設け研究計画を立 案中である。最近その二次案が微生物研究連絡委員会 に提出されたので次節でその概略を紹介する（原文は 約 80 頁にも及ぶものなので, 詳細は原文を参照された い)。

多額の金が動くところに研究者が集められたり, 研 究者が吸いよせられたりする。噮境問題は人類の生存 がかかっているだけに大義に事欠かない。しかしなが ら, 一人の人間としての研究者が技術的あるいは学問 的に自由を保ちながら，また，一社会人として嬉びを 持って，これに参加するためには予め充分検討して置

註 小沢德太郎 環境エネルギー問題一スウェーデ ソの取り組み

自然への共鳴, 黒坂三和子編 第 3 巻 地球規模の 創造的なかかわり, p. 225-254, 1990, 思索社, 東京
かなければならない問題る沢山含んでいる。

まず，環境問題に対する基本認識の問題がある。ス ウェ・デン大使館員の小沢徳太郎氏の言葉を借りれ ば,“「国民の生命と福社」がすべてに優先すること,「科 学も, 政治も, 法律もそれに奉仕する道具にすぎない」” と云うことと“人間の活動は基本的には污染行為で ある」と認識した上で「その人為的な污染行為をその 時々の最良のしか子経済性を伴ら技術で最小限に抑へ 込さ」と云らスウェーデン政府の認識をどら受け留 めるかであっ。この問題は又別の機会に諭ずることと したいぶ，仹の小沢氏の論説を是非参照されたい。

\section{2. 日本学術会議 IGBP に関する第二次案}

\section{i) 立案の経緯}

この研究計画は1982 年 IUGG の国際観測年 25 周 年記念会合で, 会長の G. Garland 教授が発議し, それ がIUGG から国際学術連合 (ICSU) に提案されたも のである。

ICSUは1984年各国の研究者（日本からは服部明 彦教授) で構成される特別計画部会 (ad hoc planning group) を設け検討が始められた。2 年間の検討の後, い くつかの課題についての研究計画指針が望とめられ， 1986 年の ICSU 総会で 1990 年から実施することが承 認された。これをうけと1986年, IGBP特別委員会 (SC-IGBP, 委員 19 名 11 ケ国, 委員長 Dr. J. McCarthy, 日本からは根本敬久教授が委員となっている) が 結成され, IGBP 憲章と組織規約が作られた。SC-IGBP は3 回の会合を重ね, 詳細な研究計画案の大綱をつく り, 組織規約に従いIGBP 特別諮問委員会 (SACIGBP) に付託した。そして SC-IGBPはSAC-IGBP の 意見を参照しつつ最終計画案を立案中である。 
日本学術会議は, 会長の私的諮問委員会 (IGBP 打 合せ会議, 座長大島康行教授, 委員 26 名) を設け, 研 究計画案を作成した。

その後, 1989 年 7 月「人間活動々地球環境」に関す る特別委員会 (委員長吉野正敏教授) はIGBP 分科会 (委員長大島康行教授) を設置し, 日本の IGBP に関す る研究計画の実施について政府に勧告するため，上記 IGBP 打合せ会議に拈いて作成した案について検討を 行い，第 2 次案 (1990年 2 月) を作成した。

この計画案は地球の変化を, 地球圏と生物圏の相互 作用に重点を掞いて解明するこ上る目指した研究計画 である。

\section{ii) 計画の内容 (国際的合意内容)}

この計画の目的は「生命をはぐくんでいるかけがえ のない環境, 全地球システムで起こっている変化,さ らに, 人間活動による影響の在り方を, 全地球システ ムを調節している物理的, 化学的, 生物的過程の相互 作用の面から記述し，理解することにある」と述べて いる。

この目的に合わせて, 次の 4 研究領域と, 研究を進 めるための 4 つの核となるプログラムが計画された。 即ち

\section{領域研究}

（1） 陸上生物圏 一大気圏の化学的相互作用

(2) 海洋生物圏一大気圏の相互作用

（3）水循環と生物圏

（4）陸上生態系に対する気候変化の影響

以上領域研究, 以下共通プログラム

（5）全地球規模の地球圏 一生物圏モデリング

（6）データ扣よび情報システム

（7）過去の環境データの抽出技術とその収集

（8）地球圏 一 生物圏観測所網

(この案は前記 SAC-IGBP で承認されているとのことで あり, 詳細な実施計画案も大笳に沶いて承認されている)

また現在までに IGBP に関係ある国際協同研究は政 府機関や非政府機関を通じて 10 種註あり，また， UNEP, UNSCO 等の組織とも密接に連絡をとる必要 があると云っている。

\section{iii) わが国の研究計画}

わが国では前記の国際的合意内容を受けて，学術会 議の特別委員会で検討し, (1) 地球変化は地球の物理・ 化学・生物の諸過程の複雑な相互作用によって招り, そ
の解明には従来には例をみない多数の分野の研究者 が，それぞれの課題ごとに密接に協力して研究を行ら ことが必要であること，(2) 国際研究計画に積極的な 役割を果たしていくためには，十分な国際的，地域的 協力のもとに独創的な研究を進めること，(3) 日本の 地理的条件々研究者層, 研究の現状を考慮して研究対 象地域を設定すること，が確認された。

以上の点から広義のモンスーンアジア地域, 西太平 洋地域, 極域を主要な研究地域とし, 次の 7 つ研究 領域の各課題について研究を進めることが決定され た。

1. 大気微量成分の変質および生物圏との交換

2. 海洋に和ける物質循環と生物生産

3. 陸上生物群集への気候変化の影響

4. 気圏・水圏・陸圏と生物圏の間の相互作用を考 慮した気候解析とモデリング

5. 環境変化のモニタリング

6. 古環境の変遷

7. 地球環境と人間活動の相互作用

これらの研究領域と国際研究領域との関係，および 日本の各領域間の関連は次の通りである。すなわち, 国 際研究領域の (3) 水循環と生物圏, (8) 地球圏-生物圏 観測所網は日本の領域には対応するものがないが, (3) は本研究領域 1,3 の研究課題に含まれる。(8) は $1,2,3$ の研究領域で観測地点を必要とする。すなわち, モンスーンアジ地域, 西太平洋地域に持ける関係各 国の地域協同研究を進めるなかで協同観測地点を決定 され，一方国際的な観測所網も確立される。

国際研究領域には人間活動に関連した研究領域が確 定していないが，わが国としては特にIGBP の研究遂 行に必要な情報の収集，整理，分析や，続いて推進さ れるHDGCP に連続される研究を，IGBP の中で実施

註 GEWEX: Global Energy and Water Cycle Experiment.

IGAG: International Global Atmospheric Programme.

IHP : International Hydrological Programme.

IUGC : International Global Atmospheric Chemistry Programme.

JGOFS : Joint Global Ocean Flux Study.

MAB : Man and the Biosphere Programme.

SCOPE : Scientific Committee on Problems of the Environment.

SCOR: Scientific Committee on Ocean Research.

STEP : Solar Terrestrial Energy Programme.

WORP : World Climate Research Programme. 
する必要があるため，研究領域の 7 を加えた。

この研究計画は 1990 年から 10 年間行われるが, 前 期 5 年, 後期 5 年の計画となっている。課題と推進方 法については随時再検討を行ら方針であるとしてい る。

次に各領域の研究内容を研究課題を含めて簡単に紹 介する。

研究領域 1. 大気微量成分の変動执よび生物圏との 交換

$\mathrm{CO}_{2}, \mathrm{CO}, \mathrm{CH}_{4}$, 非メタン系炭化水素類 (NMHC), $\mathrm{N}_{2} \mathrm{O}$, 八ロゲン化炭素類 (CFC, HCFC, HCC, CC), 等の気体はすべて赤外熱放射に対して活性であるた め，温室効果を及ぼす。その気体を対象に大気圈に扤 ける物理的，化学的動態拈よび生物圏との交換過程を 定量的に解明する。以下の分科課題よりなる。

研究課題 1 アジア大陸気団と太平洋気団の物理化 学的特性

人的起源执よび自然界の微量気体およびェアロゾル が，太平洋上の対流圏に与える影響，さらに降下物を 通して海洋に与える影響を解明する。

研究課題 2 熱带アジアに打ける気体・粒状物質の 発生とその影響

微量気体およびェアロゾルの発生源として熱帯の重 要性が指摘されている。（特に土地利用形態の変化が 急速に進行している場合) 現地研究者と協力して, 大 気濃度と大気への排出量の測定を実施し，広域分布図 の作成のための基礎資料を得る。

\section{研究課題 3 生物圏との気体交換流量}

生物圏から大気圏に供給される微量気体の正味の交 換量について，グローバルな分布図を作成する。この ことは微量気体濃度の長期変動の原因を分析し，人間 活動による影響を評価する上で不可欠である。

\section{研究課題 4 南極域に打计る大気変質}

南極域は人間活動も含めて生物活動度の低い地域で あり, 人間活動による直接的影響が少ないので,グロー バルな大気変動をモニターするのに適した場である。

また，南極域はオゾンホールの存在に代表されるよ らに, 特殊な気象的, 大気化学的状態が顕現する地域
でもあり，そらいった条件下での観測によって，大気 中の複雑な物理的, 化学的過程を分離抽出して究明し, 大気力学, 化学のグローバルモデルの検証をすること ができる。

研究領域 2 海洋に打ける物質循環と生物生産

海洋は大気圏に比べて 270 倍の質量と 1,100 倍の熱 容量を持つ巨大なリザーバーであると見ることができ る。したがって，大気圈との界面を通して行われる両 者間の物質扣よびエネルギー交換は大気圏に大きな影 響を与光，ひいては地球環境全体の変化を導く要因と もなりらる。この関係を明らかにするため，次の 4 課 題について研究する。

研究課題 1 大気 一海洋間の物質交換

温室効果を示すことで問題となっている各種気体の 大気一海洋間の交換係数々気体物質の海水中濃度の 時間・空間的変動を測定する。それらの結果に室内実 験の結果も加光て各物質の交換量 (逃散量) を見積 り，それらを支配している要因を明らかにする。

研究課題 2 海洋生物 一物質循環間の相互作用 海洋生物とその物理的環境の相互作用を解明するた め次の 5 分科課題を中心に解析する。
a) 生物生産および炭素循環に関する海水流動
b) 海水中溶存成分による環境変動
c) 沈降粒子束観測による海洋物質循環
d) 海洋に打ける一次生産量とその制限因子
e) 海洋生態系の質的構造の把握とその変動の解 析

研究課題 3 海底の生態系之物質循環 海底が海洋全体や地球環境変化に対して，どの程度 の役割を演じているのかを明確にするため,

a) 海洋物質循環に果す海底の役割

b) 熱水域などの海底生態系とその変動 の二方向から研究する。

\section{研究課題 4 沿岸海域における諸過程}

$1,000 \mathrm{~m}$ 以浅の海域は全海洋の $12 \%$ を占めるに過ぎ ないが，生物生産や物質循環は極めて活発で，量的に も外洋域以上の重要性を持つ場合が少なくない。そこ で,この海域について

a) 沿岸域から外洋への物質フラックス 
b) 縁辺海域に打ける物質生産とそれが物質循環 に果たす役割

c）陸域環境変化による河口，大陸棚域の環境々 生態系の変化

\section{研究課題 5 極域と地球環境変化}

極域は気温や大気中オゾン濃度の変化ばかりでな く，海洋に扔いても地球環境変化の影響を最す受け易 い地域であると見なされている。

海水そのものに関することや極海の水の動きに関す る研究は別のプログラムで取り上げられる可能性があ るので，ここでは生物生産過程と物質循環に限って研 究する。

\section{研究領域 3 陸上生物群集への気候变化の影響}

陸上生物群集の多くは大気圈扣よび水圏, 地圏々. ネルギー拈よび物質の交換を活発に行って招り，その 過程で多量の温室効果気体を吸収したり，排出したり している。

その他，植物の蒸発散過程を通じて地域の水収支条 件や気候形成過程へも作用している。これらの過程は, 大気組成とそれに伴ら気候変化によって左右される が，定量的関係は殆ど明らかにされていない。人為的 に生じている大気組成の急速な変化（地質時代にくら べて 10 万倍も速い) をらまえて，上記問題を解明す る。

研究課題 1 生物機能への大気組成・気候の変化の 直接的影響の解明

環境調節実験チャンバーを用いて，下記課題につい

て定量的実験を行い,それを基にモデル作成を試みる。

a) 植物の光合成・蒸散活動への大気組成と気候 変化の影響

b) 植物の物質生産構造への大気組成と気候変化 の影響

c) 動物の機能への大気組成と気候変化の影響

d) 生物機能への大気組成と気候变化の影響のモ デル化に関する研究

e) 植物の生長・乾物生産過程への大気組成と気 候変化の影響のモデル化に関する研究
研究課題 2 陸上生物群集でのエネルギー・物質交 換と炭素バランスへの気候変化の影響 の解明

陸上植生地でのエネルギー・物質の交換, 炭素バラ ンス拉よびメタン, $\mathrm{N}_{2} \mathrm{O}$ 等の温室効果気体の放出を, 植生・土壇・気候の各条件との関連に打いて観測する。 東アジアーモンスーン地域の主要植物群集内に観測点 を設ける。その分科課題は次の通りである。

a) 林地に和けるエネルギー・物質の交換と気候 条件との相互作用

b) 耕地に打けるエネルギー・物質の交換と気候 条件との相互作用

c）主要な陸上植物群落に抢ける炭素バランスの 気候条件・人間活動の影響の解明

d) 土壤有機物の分解への土壇条件・微生物条 件・気象条件の影響の解明

e) 陸上植生地からの $\mathrm{CH}_{4}, \mathrm{~N}_{2} \mathrm{O}$ 流流束の実態解 明之広域評価法の開発

研究課題 3 植生地の水循環, 物質循環への気候変 化の影響の解明

植生の異なる流域に扔いて，広域水収支観測を気候 条件との関連で行い, 水収支項の動態と, 気候条件々 の関係を解明できる定量的データを収集する。これら のデータから物質循環に対する気候変化招よび酸性雨 の影響を解明する。分科課題は下記の通りである。

a) 流域水収支と植生条件との関係の比較

b) 流域水収支への気候変化の影響の解明と評価 法の開発

c) 流域の水循環と物質循環との相互作用の解明

d）土畩層内の無機・有機成分の動態への酸性雨 の影響の解明

e) 流域の物質循環への酸性雨の影響の解明

研究課題 4 陸上生物群集の構造分布への気候変化 の影響の解明

植物生産力一気候モデル，植物種分布一気候分布 モデルなどを用いて予想気候変化の植物生産力，植物 群集，扣よび動物群集の分布などへの影響を評価する 方法の開発を試みる。その結果を用いて近い未来の高 $\mathrm{CO}_{2}$ 気候条件下での陸上植物群集の構造・生産力・分 布の変化を評価する。さらに各生態系への生物エネル ギー流入量を評価し，これに基づいて，陸上生物群集 の多様性・構造・分布の予想される变化を明らかにす 
る。分科課題は下記の通りである。

a) 陸上植物群集の純一次生産力に対する高二酸 化炭素気候变化の影響解明

b) 生物群集の分布と気候変化との関係の生物地 理学的解明

c) 高二酸化炭素気候変化化伴う植物群落分布移 動の理論的解明

d) 陸上生物群集の種多様性への気候変化の影響 の解明

e）陸上生物群集の構造・分布への気候変化の影 響の解明

f） 海水位上昇の沿岸生態系への影響の解明

研究課題 5 東アジアモンスーン地域の気候・土䁃・ 植生・生物群集構造・土地利用に関する データベースの作成

広大な東アジアモンスーン地域は, 南は赤道地带か ら，北は冷温帯，亚寒帯まで広がっており，その中に は熱帯雨林, 熱帯季節林, 暖温帯林, 冷温帯林, 亜寒 帯林，乾性疎林，草原，砂漠が分布している。また，モ ンスーン気候の発達の最も著しい地域で，広大な植生 地は地域気候打よび地球気候の形成において大きな役 割を果たしている。この地域には全世界人口の約 3 分 の 2 を占める人々が住んで抢り，乙かも高い人口増加 率を保っている。このため, 多くの人々による天然資 源の利用は急速に進んで抢り，なかでも豊かな熱帯雨 林，熱带季節林は急激に減少している。これらの植生 破壊は，地表一大気間に抢けるエネルギー・物質交換 に大きな変化を与え，気候形成過程に乱れをもたらす 可能性がある。

しかしながら，この地域の多くで気候・土壤・植生・ 土地利用に関するデータの整備は極めて遅れている。 その整備のため以下のことを行う。

a) 東アジアモンスーン地域の気候資源のデータ 収集とデータベース化

b) 東アジアモンスーン地域の土壌資源のデータ 収集とデータベース化

c）東アジアモンスーン地域の生物群集構造デー タの収集とデータベース化

d) 東アジアモンスーン地域の土地利用データの 収集とデータベース化
研究領域 4 気圈・水圈・陸圈と生物圈の相互作用を 考慮した気候解析とモデリング

研究領域 $1,2,3$ 打よび 6 で得られた知見とデータを 結集し, 自然条件での過去の気候変動および人為的な 環境污染の影響を合わせて，大気・水および生物の間 の相互作用を解析する。

また，各領域の研究者が連携して，それぞれの分野 の波及作用や相互作用をモデル化し，全地球規模の大 循環モデル，あるいはアジア地域などのリージョナル モデルに連結することにより，総合的な数值計算を行 ら手法を開発する。

そして，最終的には，これらのモデルにより，環境 変動に関係する物質の影響評価, 地球全体の環境容量 の見積りと将来の気候, 環境の变動予測, 特定地域の 特定生物に注目した環境と生態予測などを行い，環境 保全策に資する。さらには，領域 5 と関連して，今後 の気候，環境の状態を監視，解析するために必要な測 定要素，モニタリング法などについても検討し，拡充 や補完を要請する。

\section{研究課題 1 物質循環のモデリング}

大気と地表, 海表面の熱エネルギーや水分の交換過 程を組み入れて, 気流, 気温, 大気中水分, 降水, 大 気污染物質などの分布と変化を, 長期にわたり全地球 規模で数值計算するモデルを開発する。

分科課題は次の通りである。

a) 全地球スケール大循環モデル

モデルの開発に当たっては，各々の現象を結合して 計算する大気大循環と，これに連結する各因子や境界 条件を支えるコンポーネントモデルを構築する。

b) 資料収集および測定の要請

GBO (世界総合観測所網) などの他のプロジェクト と連絡をとりながら，大循環モデルを開発するのに必 要なデータを収集する。また，データが不足あるいは 測定していない要素については，関係機関に測定を要 請する。

研究課題 2 リージョナルスケールの気候・環境の モデリング

気象, 環境の变化を特定の地域の植生や農産物々結 びつけて，現況を解析したり，将来の状況を予測しら るモデリングを行う。

分析課題は次の通りである。 
a) リージョナルスケール気象モデルの開発

大循環モデルに加わる中規模現象をモデル化して結 合する。長期変動する内子は大循環モデルで支光, 特 定の地域や特定の動植物に焦点をあてた計算ができる ようにする。

b) 資料収集执よび測定の要請

大循環モデルのための資料に加えて，リージョナル モデルの開発に必要なデータを補完する。

研究課題 3 気候変化および人間活動と生態系のシ ミュレーション

大気污染, 水質污染, 森林乱伐, 海洋埋め立てなど の人為的行為が地球全体の気候に与える影響を, 大気, 海洋, 植物の間の相互作用を含めて, 数值シュミレー ションし, 自然現象と人為的影響を比較評価すること により，保全対策の必要性を検討する。

研究領域 5 環境変化のモニタリング

広域の植生, 土壤水分, 雪水执よび海洋基礎生産力 などの時間一空間分布とその変化とは, 種々の微量気 体や水の循環, 地表面アルベド, 大気の熱収支などに 影響を与え, 気象, 気候とフィードバックシステムを 形成している。したがって, 地球規模での自然環境変 化の研究にあたって，上記諸項目の長期にまたがるも ニタリングを実施し, それらの時間一空間分布の特徵 や変化を量的に把握することは, 第一に行らべき重要 課題の一つである。環境変化のモニタリングには, 広 い地域を同一精度で繰り返し観測することが必要で, 広域を同時に同じ測器で観測できる人工衛星や航空機 による観測は効果的である。

研究課題 1 衛星データの処理・解析法 地球環境変化のモニタリングには, 同一精度のセン サによる長期間の継続観測が必要である。しかしなが ら衛星の軌道の違い, 搭載センサの違い等があり, 観 測される面積, データの空間, 执よびスペクトル分解 能，観測時間，時期などの違いがある。それらのこと をふまえて, 下記のよらな課題について研究する。

a) 異なる衛星データの統合

b) 異なる空間・時間スケールの地表面代表值の 決定

研究課題 2 データおよび情報システム

IGBP の研究は, 対象とする地域が広大で, 複数の国
にまたがっていて，その大部分は発展途上国である。一 方研究課題の多くは学際的である。このことはデータ 抢よび情報入手などに多くの問題がある。このことに 対処するために基礎データや衛星データのらち, 共通 に利用される頻度の高いものを, 一括入手して利用出 来るよらにすること, またIGBP の研究が学際的で, そ れぞれの課題の研究成果が相互に益する所が多くある ので, 各研究成果が利用出来るような最適システムを 構築し, それによって研究の効率化を図ることが重要 である。本研究課題を次のように行ら。

a) IGBPの研究課題で共通に利用するデータ, 情報の明確化

b) 一括入手すべきデータの内容, 所在, 最優占 順位の明確化

c) 各国の IGBP 国内委員会とのデータ交換に関 する交渉

d) データフォーマットの検討, 設定など

e) 共通に利用するデータ等の入手，管理

f) データベース管理和よび利用システムの確立

研究課題 3 広域の植生モニタリング

広域の植生の長期にわたるモニタリングを行い，そ の変動を明確にして, それらのデータから広域の植生 の地理的分布の特性, 自然遷移過程, 居住環境への影 響や地圏・生物圏のかかわり合いなどを明らかにする。 そのため次のような研究を行ら。

a) 広域植生分布の資料収集。既存の植生図など の図面情報や空中写真, 衛星画像など

b) 広域植生モニタリングを行らための植生区分 法の決定。ユネスコなどにより，世界の植生の 分類法が定義されているものがあるが, リモー トセンシングデータを用いて, 植生モニタリン グを行らに適した標準的植生型の定義とその区 分法を決定し，世界共通に使用可能なものとす る。

c) 本研究実施に最適なグランドトルースエリア の整備。異なる地形, 地質, 気候帯に設立し, 詳 細な実況データ扎よび衛星データ解析に必要な 資料を収集する。

d) 植生区分，植物体执よびバイオマス量とその 変化抽出のための最適アルゴリズムの開発

e) 広域の植生执よびバイオマス量のモニタリン グ, 植生図の作成, 時間的・空間的変動量の抽 出 
f) 森林消失とそれに伴ら熱および蒸発散量の変 化のモニタリング

g) 林地, 草地の植生遷移のモニタリングおよび 人間活動に伴う植生タイプの変化の抽出

h) 植生モニタリング技術を用いた環境管理シス テムの開発

研究課題 4 土壤水分, 雪水モニタリング

土壤水分は, 水循環, 植物生態系, 気象, 気候など に関係する重要なパラメータで, これらの動態の研究 にとって, 広域の土壌水分のモニタリングの情報は不 可欠である。雪氷圏は, その高アルベドのために, 地 球大気の放射収支にとって重要であるが, 水循環の面 でも, 長期間の水の供給源として, 非常に重要な役割 を果たしている。一方，季節によってその面積を大き く変学る雪氷域の変化は, 気候の変化に鋭敏に反応す るので, 気候変動の検知器になる。そして, その変化 が広域に及ぶことから, 衛星によるモニタリングに大 きな期待がかけられている。水循環, 気候変動の研究 には, 雪水の分布のほかに多年雪水域, 雪水の水分量 などの情報も必要である。

分科課題は次の通りである。

a) 土畩水分のモニタリング

b) 雪水圏のモニタリング

研究課題 5 海洋基礎生産力のモニタリング

人間活動に伴う大気中の二酸化炭素の増加や循環の 問題には，海洋の植物プランクトンによって固定され る全炭素量 (基礎生産力) の情報が重要である。植物 プランクトンは, 海洋の大部分の有機生産を担ってい るので, その情報は, 食料問題にも重要である。時間, 空間変動の激しい海洋植物プランクトンのモニタリン グには, 広域性, 同時性および反復性に優れた特徵を 持っている人工衛星を利用したりモートセンシング手 法は特に有効である。そこで衛星データからまずク口 ロフィル濃度を, 次にクロロフィル濃度から海洋基礎 生産力を推定する方法を確立して西太平洋に打ける海 洋基礎生産力のモニタリングを行い, その時間, 空間 分布特性を明らかにする。これを次のステップで行ら。

a) クロロフィル量の推定および大気の影響など の除去アルゴリズムの開発

b) 2 年目以後に打ち上げ予定の ADEOS その他 の衛星のデータによりアルゴリズムの検証を行 5 。 c) クロロフィル量から基礎生産力を推定する方 法の開発

d) キャリブレーション用測器の開発

e）海洋基礎生産力のモニタリング执よび海洋基 礎生産力の海域特性, 経年変化などの抽出, 図 化。

\section{研究領域 6 古環境の変遷}

地球の過去の歴史を知り, われわれ人類の過去の環 境を正しくとらえることが, 将来の人類の環境変化を 予測するために必要であることは, 云うまでもない。人 間活動は，今日，急速に大きくなりつつある。現在の 変化から人為的な変化を抽出・分離するためには自然 それ自体の変化についての知見が不可欠である。

この研究領域では, 特に 12 万年前の最終間氷期の最 温暖期，完新世の最温暖期，中世温暖期や近世初めの 小水期など，特定の時期を選定して集中的に古環境の 復元を行ら。

\section{研究課題 1 大気圈の変化}

水床は降雪の連続した堆積物であり, 過去における 降雪の量や温度に加えて，当時の大気組成についての 最も精度の高い情報を保持している。南極水床の水中 の気泡の分析から, 今日, 地球の温度変化の原因とさ れている $\mathrm{CO}_{2}, \mathrm{CH}_{4}$ などの温室効果気体濃度の変化を 過去 15 万年にさかのぼって求めることができる。す た, 水中の宇宙線生成核種量から, 当時の太陽活動や 地磁気の変化についても知ることができ，このような 視点に立って下記 3 分科課題に分けて研究する。

a) 水の同位体分析, 気泡分析, 宇宙線生成核種 分析，火山噴出物分析などの氷床コア分析法の 開発

b) 水床掘削と氷床コアの分析

c) データ解析と結果の取りまとめ。

研究課題 2 海洋の変化

海洋は熱量, 物質量ともに巨大な貯蔵庫であり, 地 球環境形成に大きな役割を果している。特に西太平洋 域は黒潮, 親潮の西岸強流域で, その変化が激しい。そ こで, 同海域に扣いて海底堆積物を採取し, 微化石, 海 洋生物遺骸の種組成, 酸素, 炭素同位比などの測定に よって, 過去の $\mathrm{CO}_{2}$ などの溶存物や生物生産量の変 化, 海水温の変化を解明する。また, サンゴは海洋表 層の温度, 組成などの情報や海水面の変化をとどめて 
いる。これら海底堆積物やサンゴの研究によって, 海 域の環境変化の最も基礎的な情報を求的る。分科課題 は次の通りである。

a) 深海堆積物の微化石, 鉱物, 有機物などの分 析に上る海流系, 水温, 生物生産量, 溶存物質 などの変化の復元, ならびにその変化機構

b) イシサンゴ群体による表面海水温, 海水組成, 海面などの変化の復元

c) 沿岸堆積物, 沿岸, 海底地形の分析, 解析に よる海面変化と気候との関係の解明

研究課題 3 モンスーン・アジア地域の古環境変遷 モンスーンによって大きく特色づけられているアジ

ア東・南部の陸域環境の変遷について検討する。

湖成・陸成堆積物や古地形, 古土壤に古環境復元の 各種手法を用いて, 12 万年前以降の各時期の陸域古環 境を復元し, 環境変化のメカニズムを解明し, 最終的 には他の二大陸なみに研究水準を引き上げ, 地球規模 での環境変化の問題解決に資する。地域分けによって 分科課題とする。

a) インド亜大陸一ヒマラヤ山脈一中国内陸部

b) タイーフィリッピン一中国南部一日本

c) インドネシアーパプア・ニューギニアー オーストラリア北部

研究課題 4 歴史時代の環境変化

過去 2,000 年の環境の復元を求める。この時代は人 間による自然への働きかけが活発となり，また気候変 化や環境変化の記録が多く残されている。まず過去 300 年についての歴史天候データベースを作り, 寸で に完成されているイギリス，スイス，中国などの記録 と合わせて, 地球気候の変化を明らかにする。考古学, 花粉学, 樹木年輪学, 火山灰編年学などの分析法の進 歩は著しく, また地球化学の分析技術も向上している。 これらの方法や資料を利用して過去 2,000 年の精度の 高い古環境の復元をする。

分科課題として下記の三つを設ける。

a) 歴史天候データベースの作成ととれによる古 気候復元

b) 考古資料・年輪分析などによる古環境復元

c) 人間活動と環境変化の解明

研究課題 5 古環境のモデリング 研究領域 4 で開発された環境の数值モデルを使い，
課題 1〜4拉よび他の研究領域で得られた環境条件を 入力して数值実験を行い, 古環境の变遷を求める。分 科課題として次の 4 課題を設ける。
a) 数値モデルの整備と入力データの検討
b) グローバルスケールの研究
c) モンスーン・アジアを中心としたリージョナ ルモデルの研究
d) モデルによる将来予測

研究領域 7 地球環境々人間活動の相互作用 今日の地球規模で生じている環境変化は, 近年の急 速な人間活動によるところが極めて大きい。そのため， 一方で, 地球環境の変化拧よびそれが人間活動に及ぼ す影響を分析するとともに，他方では環境変化の発生 源ともなる人間活動を総合的に分析することが必要で ある。日本学術会議の「人間活動と地球環境に関する 見解」に示されている通り,この研究領域だけでも1つ の大きな国際的協同研究が必要であり,すでに「地球 変化の人類次元研究計画 (仮称), Human Dimension of Global Change Programme (HDGCP)」として目下 立案中である。

しかしながら，急がなければならない課題として， (1) 先行するIGBP の研究遂行に必要な人間活動に関 する情報の収集・整理・分析と（2）IGBP と HDGCP を連結する分野で, わが国としては研究が遅れている 課題とがある。この両者を推進する為に特に本研究領 域 7 設けた。

（1）に関連するものとして都市地域・工業地域から 排出されるガスの問題と農業地域に和ける焼畑農業や 森林伐採の問題がある。また，(2) に関する課題とし て, 第一次産業ばかりでなく, 第二次・第三次産業な どで多岐にわたる人間活動に及ぼす影響にかかわる問 題がある。

研究課題 1 都市・工業地域の変容と地球環境の変 化

都市・工業地域に怙ける人間活動を総合的に分析し, その構造を的確に把握し, 地球規模の環境変化との関 係を解明する。分科課題は下記の二つである。

a) 地球規模でみた都市・工業地域の人間活動

b) 地球規模の環境変化が都市・工業地域の変容 にかかわる機構 
研究課題 2 農林業活動と地球環境の変化

近代的農林業と伝統的農林業の不調和を産む農村地 域の環境悪化は, 地球上の人間定住圏の $90 \%$ 以上を占 めるが故に深刻な事態である。農村地域に打ける農林 業活動とそれにかかわる環境変化のメカニズムを, 早 急に, 詳しく解明する。分科課題は

a) 地球規模で見た農地開発・農地利用・林業生 産 (森林伐採) の変容

b) 地球規模の環境変化が農林業の変容にかかわ る機構

研究課題 3 土地利用変化と地球環境の保全

土地利用は人間活動の顔である。各種の人間活動の 結果は土地利用に反映してくる。

土地利用変化に集約でさる人間活動を制御しらるも のの主役の 1 つは水である。したがって, 特に研究領 域 3 の研究課題 2 で解明された知見を利用して, 水を 含を環境保全を考え, 来るべさHDGCP に貢献する基 礎研究を行う。分科課題として次の 2 つを設ける。

a) 世界に扣ける土地利用変化の地域特性

b) 地域計画・整備による土地利用改善と環境変 化の関係

\section{iii) 研究計画を推進するにあたって}

地球圏一生物圏国際協同研究計画 (IGBP) は全地 球システムとその変動を解明・理解するための研究で あり, 自然科学の広範な領域の研究分野が相互に複雑 にからまり合った現象の研究である。各分野の研究者 が国内の各地域や国際的に共同して研究を進め, 膨大 な研究を総合することによって初めて成果が期待され る。このため, 各省庁が協力し, わが国の IGBP 計画を 推進し, 国際的に優れた成果をあげ，主導的な役割を 果たすことが必要であり, 以下の事項について万全の 体制と措置をとることが急務である。学界・科学行政 機関が以下の事項について, 早期に具体的な方策と措 置を講じ, 日本に括ける IGBP 研究を強力に推進し, 世 界に寄与できるよう切望する。

(1) 国際対応のための体制の確立

IGBP 計画を推進するためには, 国際研究, 各領域研 究, 各国の相互の強力な協同体制と組織が必要であり, また関連する他の国際協同研究, 国際機関との協力も 必要であり, 国際的には協同研究体制が確立されつつ ある。わが国も国際的な協力体制と組織に合わせ，国 際的, 地域的研究が効率よく協力推進でさるよう, 研
究者が常時国際的連携と協力活動をしらる組織と措置 ができる体制を確立する。

(2) 研究推進体制の確立

IGBP 計画を推進するためには，この研究に関係す る大学々付置研究機関, 各省庁执よび民間の各研究機 関の各領域の研究者が交流し研究を進め, 知識を共に 有し，総合することが必要である。李た各国と協同し て行う地域研究にわが国の研究者が積極的に参加, 主 導的役割を果たしつつ研究を進めることがでさるよら にすることも必要である。これらのことが効果的に進 められるよう国内の協同研究体制と組織を確立し, 総 合化をはかる機構を確立する。

（3）国際地域協同研究体制の確立

わが国の IGBP 計画を推進し, 国際的に寄与するた めには，モンスーンアジア地域，西太平洋域，極域な ぞの地域的な協同研究を確立, 推進することが重要で ある。このためには各国の合意と緊密な協力, 協同研 究体制が必要である。このため, 地域協同研究が強力 に行えるよう，各国間の協力体制を推進するための措 置を整備する。

(4) 国際的地域研究のための研究者の養成

IGBP は総合的・学際的な研究で, しかも長期にわた る研究であり, 地域研究は今後益々重要となる。総合 的・学際的視野を持ち, 地球変化に関するそれぞれの 研究地域にかかわる国々の研究者の養成は, 研究の推 進に対し急務である。このため, 大学院博士課程の水 準の研究者の養成のための措置を確立し, 実施する。

(5) データセンター执よびモデリング計算セン ターの設立

IGBP の研究には膨大なデータの収集と管理・利用, モデリングの手法の確立とモデルによる膨大な数值計 算の効率化が重要である。そのためには高度の情報技 術を利用したデータセンター执よび超大型電子計算機 を備えた，モデル計算センターの設立が必要である。ま た，データ括よび情報交換を効率よく行らため，デー タベースの作成, 国内抌よび国際的ネットワークを構 築する。そして IGBP に関する情報システムを確立し, その実現化をはかる。また, 衛星データのりスト化, 共 有化, 国際的データの無料提供あるいは貸与を実現す る。このため, 各省庁の既存データや計画しているデー タ収集と管理・利用のためのネットワークの構築や緿 合化をはかることも重要である。

追記 1990 年 7 月には最終案が出来多少変更の予 
定である。

\section{3 微生物生態学に携わる者として IGBP にどう対応するか}

地球污染の問題は全人類の永続的生存に拘る問題で あるので，すべての研究者が人間として熟考しなけれ ばならない問題であろう。そして, 地球污染を防ぎ，人 類が生存し続け得る場を再構築する道を探し求めるこ とは全人類の使命でもあろら。

このことは政治, 経済, 人文科学, 社会科学, 自然 科学等々人間の文化すべてに拘る問題であるので, 一 人の人間としてぞの面でどら寄与して行くのかは，人 によって異なり，極めて多様な対応となろう。

前節で紹介した日本学術会議が政府に勧告を予定し ている IGBP 第二次案はその一翼を担うものとなろ う。

この案は物質とエネルギーの循環に重点を置いて， 地球圈と生物圏の相互作用を中心に地球の変化を解明 しょうとしているものと見ることがでさよう。その際 微生物生態学に携わる者としてどのような寄与をした らよいのかについて，2，3の問題点を考光て見たい。

第一の点は地球規模で物質とエネルギー循環を捕兄 るとき最も捕兄易い方法は化学的分析和よび温度変化 によって全体としての物質量およびェネルギー量の変 化を捕光ることである。その場合，微生物はその代謝 の結果の面に扮いてのみ捕光られがちとなることであ る。現時点においては, 自然の場に存在する微生物の 代謝が，その存在する環境 (微視的) や共存する他種 生物（微生物を含む）とどの上らなかかわりを持って 変化しているのかについては充分には解明されていな い。したがって，広い場の over all な代謝の結果を計 測すると同時に，その内容についての検討を進めるこ とが必要となる。差当っては，まず前者の面で over all の変動則を樹立することで足りるであろらが，将来場 の制御を考光る場合，後者の知見を抜きにしては充分 な対策を樹立することは出来ないであるら。

第二の問題点は海洋和よび土壤関係の幾らかの人々 はIGBP の現企画に余り無理をしなくても参加するこ とができそうに思觉るが，全体的に見れば研究者不足 と云わざるを得ない点である。地球規模での問題に取
組みらる微生物生態研究者や一般微生物学研究者を何 処でどのようにして育て上げるのかを真剣に考慮し， 対策を立てることが必要であろう。

第三の問題は研究の自由の問題である。最近の大学 の研究者を見ていると, 大変忙しい方々が非常に多く なり，問題をじっくり考光る時間が次第に少なくなっ て来ているよらに見受けられる。社会の管理化が進み， それに対応して大学の再編問題が大々的に進行したこ とに一原因があるように見受けられる。又技術の発展 がめざましく，のんびりしていたら取残されると云う 恐れも無しとはしない。それと同時に計測機器の発達 も目覚しく, 新しい機器を用いることにより, 新らし 、分野の研究開発が行いうることから，その基金集め の研究も行わざるを得ない面もあるよらである。この ような状況の中で, 科学研究の目指すものは何か, ま た, 研究の自由とは何か再検討する時期に来ているの ではなかららか。

また，各省庁の研究所では国の要請なるものに従っ て, 組織替之や所属替えが頻繁に行わ机ている。行政 一般の定員枠が極めて厳しく抑制されていることが一 因ではあると思われるが, 研究者の能力と活力を充分 生かす道であるとはとても思えない。政府が本当に環 境問題と真剣に取組も万と考光るのであれば，必要部 所に必要な人材を配置することを人員増を含め再考す べき段階に来ていると考光られる。わが国では科学的， 合理的思考よりも, 政治的, 行政的思考の方が優先す る傾向が強いが, この傾向を逆転させ，科学者の社会 的地位を向上させる努力が必要であろう。

このよらにIGBP の問題は，研究者各位が受動的に 参加するかしないかを考光る以上に，人類の生存をか けて, 能動的に, 微生物生態学のあり方に始交り, 社 会的問題をも含めて確信の持てる段階に至るまでお互 いに検討を深める良い機会であると考兄られる。この 問題を整理する為には恐らく，5１0 年の歳月を要す るであろらが, その過程を通して, 微生物生態学の次 なる発展への道が開かれて行くのではなかららか。次 期大会の折迄には work shopを開きたいと考㝋てい るが，大くの方々が，それぞれの御意見を御寄せ戴く ことを切浠望する。 